\title{
Re-examine Lou Go Phenomenon in Japan
}

\author{
Junko Winch (Corresponding author) \\ Centre for Languages, Culture and Communication \\ Imperial College London \\ Sherfield Building, Level 3, South Kensington Campus, London, United Kingdom \\ E-mail: j.winch@imperial.ac.uk
}

Received: July 27, 2017 Accepted: August 14, 2017 Published: September 17, 2017

doi:10.5296/ijch.v4i2.11608 URL: https://doi.org/10.5296/ijch.v4i2.11608

\begin{abstract}
This study is to re-examine the language phenomenon which occurred in Japan. Japan had undergone a linguist phenomenon called Lou Go ('Lou language') between 2006 and 2007. Lou Go had been analysed its basic grammar rule and the use of vocabulary when it was in trend. However, the analysis was not linguistically studied and its implication was unknown. The objective of this study is to investigate Lou Go from linguistic perspectives and consider its implications. The research method of Lou Go's characteristics was analysed using a Lou Go text and Katakana (English borrowing words) text both quantitatively and qualitatively. Two key findings were observed. The first was that the use of English borrowing words and relexification of the word class were different, although both Lou Go and Katakana texts seems to share similarities. The relexification of Katakana text used only pronouns or nouns while Lou Go text consisted of relexification of nouns, verbs and adjectives. The second finding was that Lou Go users were usually Japanese native speakers and they did conscious code-switching which means they intentionally chose to replace certain Japanese nouns, verbs and adjectives into English. From these results, it may be possible to conclude that Lou Go was not an extension of existing Katakana and that Lou Go was not an alternative name of foreigners' Japanese. Implication of Lou Go phenomenon is that its success may be due to a combination of globalisation and Japanese educational policy at the right time and the right place.
\end{abstract}

Keywords: Code-switching, English borrowing words, Relexification 


\section{The Background}

'Since November 2006' (Yomiuri Shinbun Evening Newspaper, 2007), Lou Language or Lou Go occurred in Japan between 2006 and 2007. The literal translation of Lou Go means Lou's language in Japanese. It was a phenomenon of frequent language mixing between Japanese and the English. To avoid any confusion, Lou Go is used in this paper. Lou Ohshiba (Toru Ohshiba) is the founder and promoted it on TV programs where he is a Japanese actor/comedian in Japan. Lou Ohshiba was born at Tokyo in 1954 between Japanese parents. His father was born in China and spoke Japanese, Russian, Chinese and English. He may have had an influence from his multilingual father. His mother was from Tokyo, where they lived.

\subsection{Assumptions}

This study challenges two assumptions. The first assumption is that Lou Go is an alternative name for foreigners' Japanese speech. Foreigners' Japanese speech is usually identified by their distinctive pronunciations, the use of different vocabulary and word order or sentence structure, all of which are based on their mother tongue. The majority of the Japanese are aware of some characteristics foreigner's Japanese speech. This study does not focus on the pronunciation of non-native speakers of Japanese, but looks at the similarities and differences of Lou Go and foreigner's Japanese, focusing on the Japanese syntax. For example, the tacit understanding among the Japanese is that foreigners' Japanese speech does not have no or inappropriate function words, 'particles', in their Japanese sentences. If any evidence is found from this study, it is possible to say that the first assumption is violated.

The second assumption is that there are no significant differences between Lou Go and Katakana words or English borrowing words as Lou Go uses Katakana words. If so, Lou Go is not a new linguistic phenomenon. It is also able to claim that Katakana words were just recently renamed as Lou Go. If any differences between Lou Go and Katakana words are found, it is possible to say that the second assumption is also violated.

\subsection{Research Questions (RQs)}

Assumptions discussed above form the basis of the research questions. This study is to address two RQs below:

RQ1. What is the difference between foreigners' Japanese and Lou Go?

RQ2. What is the difference between traditional Katakana texts and Lou Go texts?

It is hoped that this study will bring the available concepts and data together and may contribute to understand Lou Go and the use of English words. In the next section, two key words related to Lou Go, Katakana and relexfication are explained before the text analysis.

\section{Katakana (Japanese Borrowing Words)}

Lexical borrowings in Japanese are dominantly English but also include other languages from around the world. Borrowing words from Chinese are called Kanji. All other foreign words are called Katakana. It is claimed that Katakana has been used since 800 to 1200AD. Hiragana is used for Japanese own words. As a basic knowledge, Japanese language consists 
of three characters types, Hiragana, Katakana and Kanji (Chinese characters). This Japanese three category system works efficiently as it allows foreign words to pass straight into the language, new sounds bearing new information. At the same time, they are kept foreigners separated from the linguistic DNA in which centuries of tradition are encoded' (Tasker, 1987. p. 32).

The first part of this section explains following three types of Katakana words: i) gairaigo, ii) wasei eigo and iii) a combination of gairaigo and Kanji, all of which will be investigated in text analysis. After these three types, this section concludes with the rule of relexification, which will be also examined in texts analysis.

\subsection{Gairaigo}

Gairaigo is Japanese and it means 'loan words from abroad' in English. Gairaigo usually undergo little or no change from their original meanings when they are used in Japanese. For example, 'character' is kyarakutā in Japanese, 'Asia' is Ajia, and Micky Mouse is Mikkī Mausu. Pronunciations of these words are slightly changed for the Japanese but the meanings are usually kept the same as the original.

The following quote shows the evidence that the fairly large number of gairaigo was already in use before World War II:

'Hundreds of English words have been incorporated into Japanese. Some of these words can be easily translated, but they are nevertheless used in the original, except in strictly Japanese compositions. So widespread is the employment of English words that a man without knowledge of English finds it almost impossible to understand all that is written in daily papers' (Nitobe, 1931, p. 262).

Furthermore, gairaigo can be combined two and more as one word. For example, rajikase means 'radio and cassette' and it is a shorten form of 'rajio and kasetto' in Japanese. Other examples include sekuhara ('sexual harassment' in English, shorten form of 'sekusharu' and 'harasumento'), ensuto ('engine stop' in English, shorten form of 'enjin' and 'sutoppu'), kopipe ('copy and paste' in English, shorten form of 'kopī' and 'pēsuto).

\subsection{Wasei Eigo}

Wasei eigo means 'Japanese-made English', which usually lose their original meanings. It is claimed that 'borrowing of a word does not presuppose knowledge of the language from which it is taken' (Methrie et al., 2000, p. 249). These examples are first given in Wasei eigo in italics and then English meaning in bracket as follows: 1) sumāto (slim and slender; 2) konsento (socket); 3) naību (sensitive and delicate); 4) key holder (key ring); 5) skinship(touching; 6) one pattern (same mannerism); 7) no sleeve (sleeveless); 8) kanningu (cheating in the exam); and 9) saido brēki (hand break).

\subsection{A combination of Gairaigo and Chinese Characters (Kanji)}

These examples include karaoke which is a combination of kanji 'empty' and the first two katakana of 'okesutora (orchestra)' and shōene which means saving energy and it is a combination of kanji, shō 'save' and the first two Katakana of 'enerugī (energy)'.

The similar combination of Katakana and Kanji is also found in Lou Go. For example, 'kenpō refōmu' means 'constitution reform' and it is a combination of kanji, kenpō 'constitution' and 
Katakana of 'refōmu' (reform). 'Chikyu hotto-ka' means 'global warming' ('chiky $\bar{u}$ ondan- $k a$ ' in Japanese) and it is a combination of kanji, chiky $\bar{u}$ 'earth' and Katakana 'hotto' (hot) and another kanji ' $k a$ ' 'change from the previous state'. These words are originally all written in Kanji.

\subsection{Relexification}

The definition of relexification is 'process of changing the vocabulary of a language while retaining its essential structure is known as relexification' (Methrie et al., 2000, p. 294). This is the most noticeable feature of Lou Go. Not only nouns but also adjectives, verbs and some other idiomatic phrases, are replaced by English words/Katakana/Lou Go, keeping the Japanese grammatical structure as a base. In other words, Lou Go's matrix language is Japanese and embedded language (Joshi, 1985, p.190-1) is English. Lou Go is a code-switching act as this occurs when the speakers know both (English and Japanese) languages and they intentionally choose to use one language for a particular reason.

Foreigners Japanese was mentioned in the assumption. It is possible to say that the matric language non-native speaker of Japanese is their mother tongue and their embedded language is Japanese. Therefore, their relexification should be different from the native speakers of Japanese. If non-native speaker of Japanese code-mix are unsure of the other language, they have no choice but to use the language they know.

\section{Method}

The study used discourse analysis to identify any differences between two texts, Lou Go and standard Katakana. In order to make the quality of the two texts similar, Tarō Asō's (2007) book was chosen. Asō was a prime minister between 2008 and 2009 and prior to this appointment, he also served as a minister for foreign affairs between 2005 and 2007. As a sample of Lou Go text, Asō's inauguration speech was used as this was coincidentally translated into Lou Go. The other Katakana text was taken from Asō's (2007) book.

Two texts were analysed using mixed methods. Quantitatively, following two points were investigated and compared: i) how many nouns, verbs and adjectives were used out of total number of each text, as well as how many percentages of relexifcation were counted; ii) what word class those relexifications were.

Qualitatively, how English nouns, adjectives and verbs were relexified was analysed in both texts. In addition, matrix language and embedded languages were also observed in order to identify whether Lou Go's relexification pattern was similar to the Japanese native speakers or non-native speakers of Japanese.

\section{Results}

This section explains the results of two texts, Lou Go and the Katakana. 
Abe Shinzo desu. Dōzo yoroshiku please itashimasu. Watashi wa sengo birth hatsu no leader daijin toshite shikkarito right na direction ni leadership wo hakki shitemairimasu. Japan wo energy to chance to yasashisa ni michiafureta kuni ni shitemairimasu. Sonotameni, today, beautiful na kuni make naikaku wo soshiki itashimashita. Japan ga world no kuniguni kara trust sare, soshite respect sare, child tachi ga Japan ni born shita koto wo hokori ni omoeru beautiful na kuni, Japan wo tukkutte mairitai to think shimasu. Dōzo yoroshiku please itashimasu. (Ohshiba, 2007, p. 151).

English translation (my translation):

'I speak to you all for the first time, to be chosen as the first leading prime minister, who was born after World War II. This country must be led firmly in the correct direction. The reason why I am here today is to form the Cabinet in order to make beautiful country, where it is filled with energy, opportunity and kindness. I wish to lead this beautiful country, Japan which other countries trust and respect, and also our children feel proud to be born as the Japanese.'

Figure 1. Lou Go text

Quantitatively, total Lou Go words used in this text are 23 out of 84 words, which is $25 \%$. There are 14 nouns, 3 verbs, 4 adjectives and 2 adverbs in the total of 23 English/Katakana/Lou Go relexifcation words. Noun relexification occupies $60 \%$ of relexification.

$\underline{\text { Nouns }}$

Nouns do not conjugate. The Japanese noun parts are simply replaced by English counterparts without changing Japanese word order. Nouns are always used in singular form. In order to make it plural, Japanese plural suffix are added following the same as the Japanese language grammar. For example, 'child-tachi (children)' in line 5, 'children' is not used. Instead, English singular form of 'child' and the appropriate Japanese plural suffix, '-tachi' is added.

$\underline{\text { Verbs }}$

Japanese verb parts are simply replaced with the English equivalent and then add Japanese verb 'shimasu' (do), such as 'think shimasu' (think) 'trust sare' (trust) and 'respect sare' (respect). There are three types of verbs in Japanese: group I, group II and group III ('do' and 'come'). Lou Go only uses group III's 'shimasu' verb conjugation. Although the ending of the group III verbs may conjugate (e.g. such as shimasu to sare), the stems of the verbs which is English remain unchanged.

$\underline{\text { Adjectives }}$

Adjective part is replaced with English counterpart. There are two types of adjectives in 
Japanese, that is, i-adjectives and na-adjectives. Lou Go conjugates following na-adjectives when they modify nouns (e.g. beautiful na kuni), adding -na suffix to the replaced English word.

There is a mismatch of a word class between English and Japanese grammatical functions. For example, 'beautiful' is an adjective in both Japanese and English which is a case where the both language's grammatical function matches. However, the mismatch occurs in other word class. For example, 'born' is an adjective, but it is used as verbs (such as born shita) in Lou Go. From these examples of mismatches, it is possible to say that Lou Go does not follow 'the equivalence constraint' (Holmes, 1992, p. 43). 'The equivalence constraint' means 'language switching occurs within sentences where the grammars of both languages match each other' (Holmes, 1992, p. 43).

\section{Sentence structure}

It is possible to say that Lou Go's matrix language is Japanese and embedded language is English. Therefore, Lou Go is different from the code-mixing which is used by the non-native speakers of Japanese.

\subsection{Katakana Text}

\begin{abstract}
'Asia no machi de Donald Duck ya Micky Mouse wo mikakeru koto wa sukunai. Pocket Monster ya Doraemon ga afureteiru. Made in Japan no, kaigai deno monosugoku ninkinoaru animation no character da. Soshite Japanese pop music no koto wo J-pop, Animation wo Japanimation, fashion wo J-fashion to yobu. Kono three J de Asia wa kanzen ni sekken sareteiru.' (Asō, 2007, p. 48).

English translation (my translation)

It is rare to see Donald Duck and Mickey Mouse in Asian cities. They are filled with Pocket Monster and Doraemon. They are the very popular animation characters overseas, which are made in Japan. Japanese pop music is called J-pop, Japanese animation is called Japanimation and Japanese fashion is called J-fashion. Asia is completely swept over by these three Js.
\end{abstract}

Figure 2. Katakana text

Contrasting to the previous text, this paragraph includes 14 Katakana words out of total of 28 words, which occupies $50 \%$ of Japanese. There are two findings. Firstly, all 14 Katakana words were nouns which consists of consisted of gairaigo (Asia, animation and character) and proper nouns such as Donald Duck. Secondly, there was no verb or adjective relexifications, which are usually observed in Lou Go. These two findings show that the Japanese people get used to these types of Katakana texts even though it includes $50 \%$ of Katakana whose main relexifications are gairaigo and proper nouns.

\section{Discussion}

Ohshiba rightly points out that Lou Go's success seems closely related to globalisation, which 
also relates to Japanese educational policy. According to Gottlieb (2007), the Japanese English education policy between 1980s and 2002 were symbolized as 'globalisation'. During the globalization policy, the Japanese government was promoting globalisation and a five-year strategic action plan of 'Japanese with English ability' (2003-8) (Gottlieb, 2007, p. 197). 'Japanese with English ability' (MEXT) five-year action plan involved designating 100 high schools as Super English Language High Schools, conducting classroom research on innovative teaching methods and encouraging both teacher and students study aboard periods in English-speaking countries.' (Gottlieb, 2007, p. 197). 'Japanese with English ability' is also combined with the government policy of Yutori Education. Around the 1972, Yutori education started as a backlash from the previous policy which focused on intense examinations in Japan.

Ohshiba has been promoting his Lou Go since 1976, but it was not successful until 2006. He analyses one of the reasons for this:

'When I was 34-35 years old, I promote Lou Go, but the reaction from the public was very cold. High school students can understand Lou Go, but it did not prevail to general public level. However, it gradually spread to the whole society maybe because of globalisation.' (Ohshiba, 2007, p. 156).

Ohshiba rightly points out that Lou Go's success seems closely related to globalisation, which also relates to Japanese educational policy. The Japanese English education policy between 1980s and 2002 was symbolised as 'globalisation'. During the globalisation policy, the Japanese government was promoting a five-year strategic action plan of 'Japanese with English ability' (2003-8) (Gottlieb, 2007, p. 197). 'Japanese with English ability' (MEXT) five-year action plan involved designating 100 high schools as Super English Language High Schools, conducting classroom research on innovative teaching methods and encouraging both teacher and students study aboard periods in English-speaking countries.' (Gottlieb, 2007, p. 197). 'Japanese with English ability' is also influenced by the government policy of Yutori Education. Around the 1972, Yutori education started as a backlash from the previous policy which focused on intense examinations in Japan.

'Japanese with English ability' stresses oral communication English classes, innovative teaching and study-abroad programs. High school students wished to speak English and approximated their speech to Ohshiba who sounded bilingual. In a way, Ohshiba introduced how bilingual talk to the general public. Lou Go may have contributed to achieve the government policy of 'Japanese with English ability'. The success of Lou Go phenomenon may be due to a combination of globalisation and educational policy. Globalisation influenced the Japanese educational policy and Lou Go may have been there at the right time and the right place.

However, MEXT announced a new educational policy in August 2007 following the devastating Japanese Program for International Student Assessment (PISA) result on December 2006 after the Yutori policy which lasted for about 30 years. PISA showed that Japan dropped its ranking in all three subjects compared to the previous test: Reading dropped from the fourteenth to the fifteenth position, and mathematics literacy dropped from 
the sixth to the tenth position, and science literacy from second to sixth position (MEXT, 2007). MEXT analysed the cause of dropping in its rankings as the inability to use the Japanese language. MEXT stressed on importance of Japanese language in contrast to the previous policy.

The focus of the government shifted from English to the Japanese language. This movement coincides with Japan in the $19^{\text {th }}$ and $20^{\text {th }}$ century, when Japan experienced too many foreign ideas imported after officially opening Japan, the Japanese tried to 'keep intact the tradition of the race' (Nitobe, 1931, p. 325) and ancient Japanese study and anthropology became popular. Most bestseller books included content such as the Nihonjinron, principle of 'one-nation, one-language' (Gottlieb, 2007, p. 198), 'a discourse that celebrates the uniqueness of Japanese culture and people' (Kubota, 2002, p. 17), etc.

\section{Conclusion}

Lou Go relexified within the Japanese sentence structure, which shows the difference between Lou Go speakers and foreigners. Lou Go's matrix language is Japanese and embedded language is Lou Go. Lou Go speakers know both Japanese words and English words, and they intentionally choose to replace certain words into English only for nouns, verbs and adjectives by adding appropriate suffixes, which shows conscious code-switching. This violates the first assumption that Lou Go is alternative name of foreigners Japanese.

A Lou Go text and Katakana text were compared and analysed. The finding is not the number of relexification but the type of word class. The Katakana text use only noun relexfication, either pronouns or nouns. On the other hand, Lou Go consists of relexification of nouns, verbs and adjectives. Furthermore, how to make plural nouns also followed Japanese grammar, replacing English singular form and adding Japanese appropriate suffix. These characters were not observed in the traditional Katakana texts. This violates the second assumption that Lou Go is merely renaming of Katakana text. It is possible to say that Lou Go was not the extension of existing Katakana.

An increasing number of people are studying Japanese. This study may contribute to Japanese language learners and teachers who wish to add Lou Go as one of their knowledge of Japanese dialects during the course of their Japanese teaching and learning experience.

This study may also contribute to the knowledge on sociolinguistics study as a Japanese language case study. The majority of case studies for code-switching compare local dialects in European languages and minority languages. With the current globalised teaching and learning environment in mind, it may be suggested to include code-switching case studies from non-European language in the sociolinguistics textbooks. This may increase the interest of language learners from a variety of cultural backgrounds and stimulate sociolinguistics study.

\section{References}

Asō, T. (2007). Totetsumonai Nihon. Tokyo: Shinchosha.

Gottlieb, N. (2007). Japan. Oxford University Press. 


\section{Macrothink}

Holmes, J. (1992). An Introduction to Sociolinguistics. Pearson Education.

Joshi, A. (1985). Processing of Sentences with Intrasentential Code Switching. In Dowty, D. R., R., Karttunen, L. \& Zwicky, A. (Eds.), Natural Language Parsing. Cambridge University Press. https://doi.org/10.1017/CBO9780511597855.006

Kubota, R. (2002). The impact of globalization on language teaching in Japan. Routledge.

Methrie, R., Swann, Deumert, J. A., \& Leap, W. L. (2000). Introducing Sociolinguistics. Edinburgh University Press.

Nitobe, I. (1931). Japan. Ernest Benn Ltd.

Ohshiba, T. (2007). Lou Go Daihenkan. Tokyo: Fusousha.

Tasker, P. (1987). Wealth, Work and Power in the New Japanese Empire. Penguin Books.

The Ministry of Education, Culture, Sports, Science and Technology in Japan (MEXT) (2007). OECD Seto no Gakushu Tota Tōtatsudo Chōsa: 2006 nen Chōsa Kokusai Kekka no Yōyaku, Retrived 13 September, 2015 from http://www.mext.go.jp/a_menu/shotou/ gakuryoku-chousa/sonota/071205/001.pdf

\section{Copyright Disclaimer}

Copyright reserved by the author(s).

This article is an open-access article distributed under the terms and conditions of the Creative Commons Attribution license (http://creativecommons.org/licenses/by/3.0/). 